\title{
Effect of gut microbiota modulation on feeding tolerance of enterally fed critically ill adult patients: a systematic review
}

\author{
Najmeh Seifi ${ }^{1}$, Ali Jafarzadeh Esfahani ${ }^{1}$, Alireza Sedaghat ${ }^{2 *}{ }^{*}$, Reza Rezvani $^{1}$, Majid Khadem-Rezaiyann ${ }^{3}$, \\ Mohsen Nematy ${ }^{4}$ and Mohammad Safarian ${ }^{4^{*}+}$
}

\begin{abstract}
Purpose: The objective of this systematic review was to evaluate the effect of pre-, pro-, and synbiotics on feeding tolerance of enterally fed critically ill adult patients.

Methods: MEDLINE, Science Direct, Web of Knowledge, and the Cochrane Central Register of Controlled Trials were searched up to November 2019. English language randomized controlled trials reporting the effect of pre, pro or synbiotics on the feeding tolerance of enterally fed critically ill adult patients were included.

Results: Overall, 15 papers were selected for review. Among six studies reporting the energy intake, only two studies showed significantly higher energy intake in the prebiotic-receiving groups. Among four RCTs reporting frequency or time to achieve the target calorie, only one found a significant effect of probiotics to reduce the time to achieve a target dose of calorie. About the prevalence or duration of diarrhea, 7 out of 12 RCTs reported a beneficial effect. All but one study found no beneficial effects for gut microbiota manipulation on clinical endpoints including length of stay (LOS) in hospital and intensive care unit (ICU).

Conclusion: It should be noticed that the heterogeneity in study designs, product format, and ICU patient populations makes it difficult to draw any general conclusion. Overall, it seems that pre, pro, or synbiotics have no significant beneficial effect on feeding tolerance and clinical endpoints in critically ill adults, but they may reduce the prevalence or duration of diarrhea.
\end{abstract}

Keywords: Prebiotics, Probiotics, Synbiotics, Gut microbiota, Feeding tolerance, Critical care

\section{Background}

Critical illness can cause hypermetabolism and hypercatabolic state that quickly depletes nutritional reserves, alters immune function, and predisposes individuals to morbidities and mortality $[1,2]$. Critically ill patients are also likely to experience severe changes in gut function. These changes are due to alterations in gut muscle

\footnotetext{
* Correspondence: Sedaghatar@mums.ac.ir; Safarianm@mums.ac.ir

${ }^{2}$ Department of Anesthesiology, Mashhad University of Medical Sciences, Mashhad, Iran

${ }^{4}$ Metabolic Syndrome Research Center, Mashhad University of Medical Sciences, Mashhad, Iran

Full list of author information is available at the end of the article
}

contractions, secretion, and absorption. Gut microbiota disturbances and epithelial barrier disintegration are also involved [3-5]. In this situation, early-onset and the proper amount of nutrition support are of great importance [6]. Enteral nutrition (EN) is regarded as the favored root of nutrition support, because it protects the gut barrier, modulates immune responses, and leads to a faster return of gut function. However, many critical care patients cannot receive EN due to tolerance problems $[4,6]$.

Enteral feeding intolerance is a common problem among critical care patients. It is often defined as either 
or both of the following conditions: reduced delivery of EN and presence of gastrointestinal (GI) symptoms, including diarrhea, vomiting, regurgitation, abdominal distention, and high gastric residual volume (GRV) [7]. Feeding intolerance often results in failure to achieve the target nutritional dose as well as increased risk of pneumonia and intensive care unit (ICU) stay [8]. Factors associated with feeding intolerance in critically ill patients include stress-induced hyperglycemia; hormonal disturbances (including high levels of cholecystokinin (CCK), and peptide YY (PYY), and low levels of motilin); administration of sedatives, analgesics, and vasopressor agents; and disturbances in gut microbiota. These factors finally result in gastrointestinal dysfunction and manifest as feeding intolerance [9].

Gut microbiota manipulation can affect enteral feeding tolerance and energy homeostasis through several mechanisms. Administration of pre, pro, or synbiotics are different ways of gut microbiota manipulation. Probiotics are live microorganisms that have beneficial health effects if administered in optimum amounts. Prebiotics are non-digestible oligosaccharides that promote growth and/or activity of specific bacteria in the gut. Synbiotics are products with a combination of probiotics and prebiotics [10]. Altering gut muscle contractions, secretion, and absorption [11-13]; regulating glucose homeostasis $[14,15]$; and affecting hormonal and immune responses, host metabolism, and feeding behavior [16] are known mechanisms by which gut microbiota modulation can affect feeding tolerance and energy homeostasis.

Recently, the relationship between gut microbiota and nutrition, especially in critically ill patients has been attracting considerable interest. Many studies have reported the effect of pre, pro, or synbiotics on EN volume, energy intake, or EN-associated complication. Nevertheless, to the best of our knowledge, no systematic review or meta-analysis has been conducted to evaluate the effect of pre-, pro-, and synbiotics on feeding tolerance of enterally fed critically ill adult patients.

\section{Methods}

This systematic review was consistent with the Preferred Reporting Items for Systematic Reviews and MetaAnalysis (PRISMA) statement (Additional file 1) [17].

\section{Search strategy}

A systematic search of randomized controlled trials published until November 10, 2019, was independently conducted by two authors (NS, AJE) on MEDLINE (via PubMed), Science Direct (via Scopus and Embase), Web of Knowledge (via Web of Science), and the Cochrane Central Register of Controlled Trials (via Cochrane Library). The search strategy was designed in accordance with the database orientations using Boolean operators
(AND, OR), parenthesis, quotation marks, and asterisks. The following search strategy was used in MEDLINE: ("critical" OR "critical care" OR "critical illness" OR "critically ill" OR "critically unwell" OR "severely unwell" OR "severely ill" OR "intensive care" OR "ICU" OR "CCU") AND ("tube feeding" OR "enteral" OR "enteral feeding" OR "enteral nutrition" OR "force-feeding" OR "nasogastric" OR "nasoduodenal" ${ }^{\text {" }}$ OR "nasojejunal") AND (prebiotic" OR probiotic" OR synbiotic* OR symbiotic) NOT (child OR pediatric OR infant OR preterm OR neonate) OR ((“Enteral Nutrition”[Mesh]) AND ("Critical Care"[Mesh] OR ("tolerance" OR "intolerance" OR "tolerant" OR "intolerant") OR ("diarhea" OR "diarhoea" OR "distension" OR "distent")) AND ("Probiotics"[Mesh] OR "Synbiotics"[Mesh] OR "Prebiotics"[Mesh])). Language restriction was applied to select articles in English. Furthermore, a manual reference check was conducted on the identified articles to find further relevant studies.

\section{Screening and eligibility of records}

The Population, Intervention, Comparison, Outcome, and Study design (PICOS) strategy was used to identify inclusion criteria. The inclusion and exclusion criteria are presented in Table 1. In summary, RCTs that were published in English language; included adult critically ill patients undergoing tube feeding; administered pre, pro, or symbiotics in the intervention group and placebo or routine care to the control group; and assessed enteral feed volume, time to reach full enteral nutrition, the prevalence of feed intolerance, and related GI complications were included in the review. Studies that included patients who received partial EN or in vitro studies were excluded. Based on the review protocol, author of studies that seemed to include other outcomes in the study but failed to report the results were contacted and asked for the missing data to avoid reporting bias. Unfortunately, the authors either did not respond to the email in the designated time of the review or the data were not available for further analysis.

The title and abstract of all identified articles were independently screened by two authors (NS, AJE). Randomized controlled trials that assessed the effect of pre, pro, and synbiotics on feeding tolerance in tube-fed critically ill patients were selected. The full text of selected articles was read and assessed regarding compliance with established eligibility criteria. Discrepancies were resolved by discussion with a third researcher (RR).

\section{Data extraction and synthesis}

The following variables were considered in data extraction: title, authors, year, country, study aim, population features (sex, age, number of participants), experimental design, intervention (the composition of prebiotic, 
Table 1 PICOS criteria for inclusion and exclusion of criteria

\begin{tabular}{lll}
\hline Parameter & Inclusion criteria & $\begin{array}{c}\text { Exclusion } \\
\text { criteria }\end{array}$ \\
\hline Population & Adult tube-fed critically ill patients & Partial EN \\
Intervention & Supplementation with pre, pro, or synbiotics \\
Comparison & Placebo or nothing & Enteral feed volume, Time to reach full enteral nutrition, the prevalence of feed intolerance and related Gl \\
Outcome & complications (diarrhea, distention, high residual volume) & In vitro studies \\
Study & Randomized controlled trials & \\
design &
\end{tabular}

EN Enteral nutrition; GI Gastrointestinal

probiotic and synbiotic, dose, and timing of administration), and main results. The $I^{2}$ statistics was used to assess heterogeneity of the studies. The analysis indicated that the heterogeneity of the studies was high (74\%). The source of heterogeneity in the included articles in this systematic were study population, inclusion and exclusion criteria, intervention, duration, and reported outcomes. Due to the heterogeneity, further statistical comparison was not possible. Therefore, vote counting was the method used for data synthesis. The vote counting strategy was performed to sum up the findings of the included studies [18]. Vote counting was performed based on the risk of bias, sample size, and the statistical significance of the findings of the included studies. The harvest plot was then used to present the findings of the vote counting with colors representing studies, bar width representing sample size, and bar height representing study quality (JADAD score).

\section{Risk of bias assessment}

The 5-point JADAD score was used independently by two authors (NS, AJE) to assess the quality of included studies. Discrepancies were resolved by discussion with a third researcher (MKR). The five domains of the JADAD score included being randomized, appropriately describing of randomization, being double-blind, appropriately describing blinding, and explanation of withdrawal and dropouts.

\section{Clinical outcomes}

In this study, feeding intolerance was defined as either or both of the following conditions: reduced delivery of EN and presence of GI symptoms, including diarrhea, vomiting, regurgitation, abdominal distention, and high GRV. So, the clinical outcomes of interest were enteral feed volume; energy intake, which correlates with feed volume; time to reach full enteral nutrition; the prevalence of feed intolerance; and related GI complications (diarrhea, distention, high residual volume). Diarrhea was considered as a sole outcome and was assessed based on the duration of diarrhea or frequency of defecation in patients. Length of stay (LOS) in the ICU or hospital was investigated as a secondary outcome. The treatment effect was assessed based on the presence of a significant difference in the measurement of the outcome variables between the intervention and control groups.

\section{Results}

\section{Study identification and selection}

A total of 93 relevant articles were identified through a database search and a review of reference lists of related articles. We excluded 78 articles due to the following reasons: 21 were conference abstracts, or the full text was not available, 17 were not RCTs, 13 did not exclusively enroll ICU patients, 6 were not in English, 8 did not report relevant outcomes, 5 had multiple interventions, 2 did not include exclusive EN, 1 did not have a placebo receiving control group, and 5 due to other reasons, e.g., irrelevant intervention or inconsistency in results. Finally, 15 RCTs, with a total of 1139 patients, were included (Fig. 1). As the articles included in this systematic review were heterogeneous in population, inclusion and exclusion criteria, intervention, duration, and reported outcomes, further statistical comparison was not possible. The mean JADAD score of all trials was 4.2. The minimum JADED score was 1 point for randomization. A summary of the findings of the studies is presented in Table 2. The harvest plot was presented for each outcome assessed with the orange color representing non-significant finding of the study and blue color representing significant finding. The length of the bars represents JADAD score for each study (Fig. 2).

\section{Effect on energy intake and feed volume}

Six trials examined the effect of pre, pro, or synbiotics administration on energy intake or feed volume in critically ill patients.

\section{Prebiotics}

In one trial in 2000, 44 critically ill patients receiving EN and antibiotics were randomized to receive fibercontaining or fiber-free formula and pectin or placebo for 6 days. Mean energy intake ranged from $1200 \mathrm{kcal}$ 


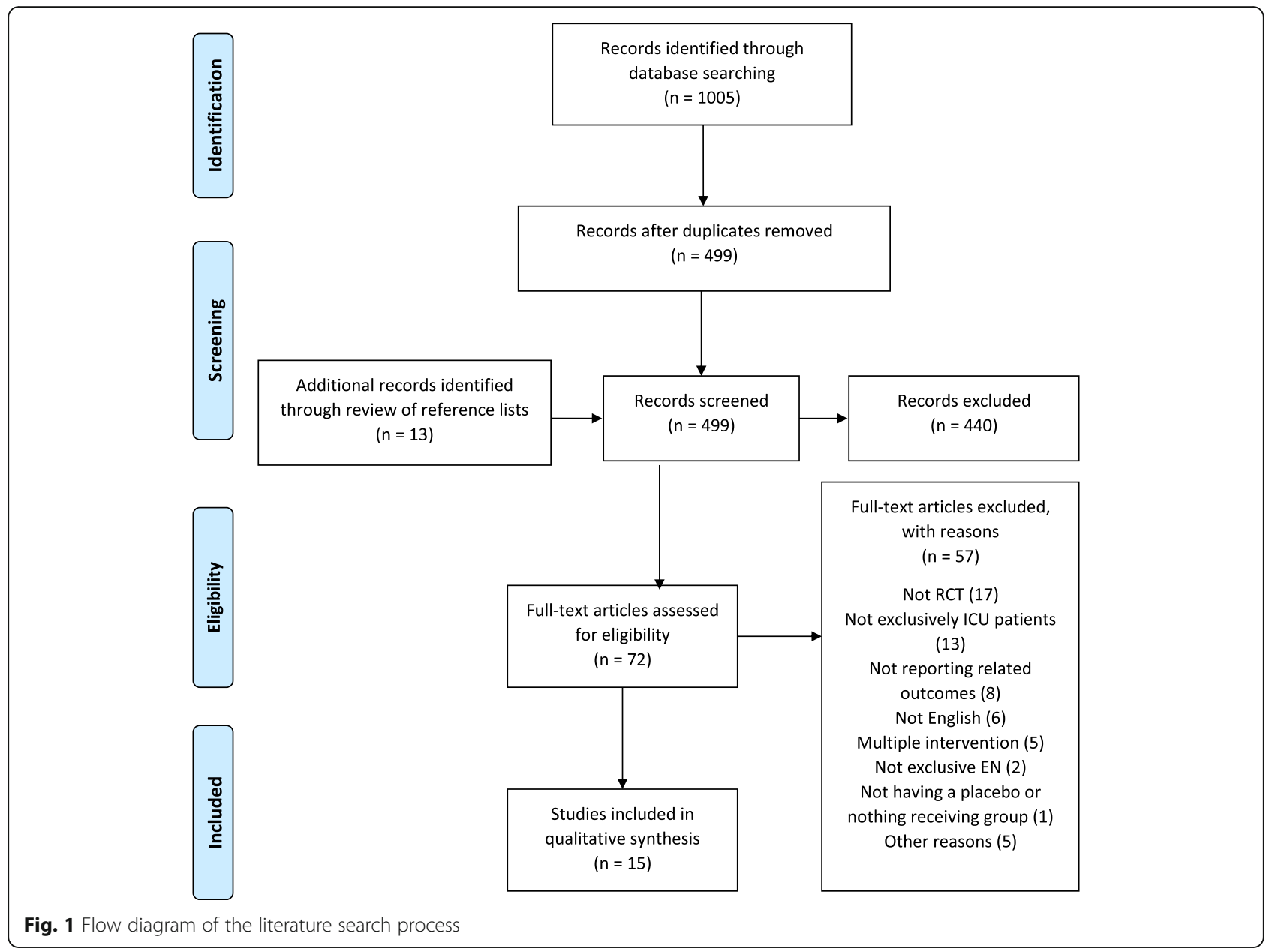

on day 1 to $1563 \mathrm{kcal}$ on day 5 . Mean energy or protein intake was not significantly different in the four study groups [19]. Rushdi et al. also evaluated the effect of guar gum enriched formula in 20 critically ill tube-fed patients with persistent diarrhea for 4 days. They showed that patients in the intervention group tolerated significantly higher formula volumes on days 1,2 , and 4 . On the fourth day, the feed volume was $1775 \pm 450 \mathrm{ml}$ in the intervention group compared to $1070 \pm 604 \mathrm{ml}$ in the controls $(p<0.01)$ [20]. In 2018, Fazilaty et al. evaluated the effect of EN containing $\beta$-glucan on inflammatory markers and clinical outcomes. They reported no significant difference in the mean tolerated calories between study groups $(1710.5 \pm 117.03 \mathrm{kcal}$ vs. $1718.2 \pm 182.4 \mathrm{kcal}$, $p=0.6)$ [21]. Tuncay et al. compared the effect of an enteral formula enriched with prebiotic versus standard EN on nutritional parameters among 46 neurocritical ill patients. Results showed that feed volume and mean energy intake significantly increased from baseline to day 21 in both groups. Patients in the intervention group tolerated a significantly higher amount of energy and feed volume on day 1 and 21 [22].

\section{Probiotics}

In a trial conducted in 2014, 40 critically ill patients were randomly assigned to receive a multi-strain probiotic or placebo for 7 days. Results showed no significant difference between groups in terms of the mean energy intake $(1503.75 \pm 231.6 \mathrm{kcal}$ vs. $1617.5 \pm 185.51$ $\mathrm{kcal}, p=0.09$ ). The percentage of patients who met energy requirements in the synbiotic and placebo groups was $84.98 \pm 3.6$ and $87.24 \pm 3.92$, respectively $(p=0.06)$ [23].

\section{Synbiotics}

Knight et al. investigated the effect of enteral synbiotic on ventilator-associated pneumonia in critically ill patients. They reported an increase in the daily tolerated feed volume from days 1 to 7 in both groups. The feed volume ranged from $488.9 \pm 622.8 \mathrm{ml}$ on day 1 to $1055.6 \pm 722.6 \mathrm{ml}$ on day 7 in the synbiotic group and from $360 \pm 431.7 \mathrm{ml}$ to $1243.9 \pm 810.3 \mathrm{ml}$ in the placebo group. There was no significant difference between the two groups regarding the mean tolerated enteral feed volume [24]. 
Table 2 Randomized controlled trials evaluating the effect of pre, pro or synbiotics on feeding tolerance of enterally fed critically ill patients

\begin{tabular}{|c|c|c|c|c|c|c|c|}
\hline \multirow{2}{*}{$\begin{array}{l}\text { Author, } \\
\text { year }\end{array}$} & \multirow[t]{2}{*}{ Population } & \multirow[t]{2}{*}{ Design } & \multirow{2}{*}{$\begin{array}{l}\text { JADAD } \\
\text { score }\end{array}$} & \multirow[t]{2}{*}{ EN protocol } & \multicolumn{3}{|c|}{ Type of intervention } \\
\hline & & & & & $\begin{array}{l}\text { Delivery } \\
\text { vehicle }\end{array}$ & Intervention /dose/duration & control \\
\hline $\begin{array}{l}\text { Bleichner } \\
\text { et al., } 1997 \\
\text { [17] }\end{array}$ & $\begin{array}{l}\text { ICU patients } \\
n=128\end{array}$ & Parallel & 5 & NR & $\begin{array}{l}\text { NGT or } \\
\text { jejunostomy }\end{array}$ & $\begin{array}{l}\text { EN (intact protein standard diet without } \\
\text { fiber or lactose) + Saccharomyces boulardii } \\
/ 500 \mathrm{mg} \text { four times a day/limited to } 21 \\
\text { days or to the withdrawal of EN }\end{array}$ & $\begin{array}{l}\text { EN (intact protein } \\
\text { standard diet } \\
\text { without fiber or } \\
\text { lactose) + placebo }\end{array}$ \\
\hline $\begin{array}{l}\text { Schultz } \\
\text { et al., } 2000 \\
{[18]}\end{array}$ & $\begin{array}{l}\text { ICU patients } \\
n=44\end{array}$ & Parallel & 2 & NR & Tube feeding & $\begin{array}{l}\text { Fiber containing formula+ pectin or fiber- } \\
\text { free formula +pectin/ } 20 \mathrm{ml} \text {, twice daily/ } 6 \\
\text { days }\end{array}$ & $\begin{array}{l}\text { Fiber containing } \\
\text { formula+ placebo } \\
\text { Or fiber-free for- } \\
\text { mula +placebo }\end{array}$ \\
\hline $\begin{array}{l}\text { Spapen } \\
\text { et al., } 2001 \\
{[19]}\end{array}$ & $\begin{array}{l}\text { ICU patients } \\
\text { with severe } \\
\text { sepsis or } \\
\text { septic shock } \\
n=25\end{array}$ & Parallel & 3 & $\begin{array}{l}\text { Start: first } 24 \mathrm{~h}, 25 \mathrm{cc} / \mathrm{h} \text {. Increase } 25- \\
35 \mathrm{cc} / \mathrm{h} \text { to } 80 \% \text { target }\end{array}$ & NGT & $\begin{array}{l}\mathrm{EN}+\text { partially hydrolyzed guar/ } 22 \mathrm{~g} / \mathrm{l} / \mathrm{a} \\
\text { maximum of } 21 \text { days or to the withdrawal } \\
\text { of EN }\end{array}$ & Fiber-free EN \\
\hline $\begin{array}{l}\text { Rushdi } \\
\text { et al., } 2004 \\
{[20]}\end{array}$ & $\begin{array}{l}\text { ICU patients } \\
\text { with } \\
\text { persistent } \\
\text { diarrhea } \\
n=20\end{array}$ & Parallel & 3 & $\begin{array}{l}\text { Start: first } 18-24 \mathrm{~h} \text {. Target: } 25-35 \mathrm{kcal} / \\
\text { kg. First day: } 50 \% \text {, second day: } 75 \% \text {, } \\
\text { third day: } 100 \%\end{array}$ & NJT & $\begin{array}{l}\mathrm{EN}+2 \% \text { soluble guar gum (Benefiber) } / 4 \\
\text { days }\end{array}$ & Fiber-free EN \\
\hline $\begin{array}{l}\text { Knight } \\
\text { et al., } 2009 \\
{[21]}\end{array}$ & $\begin{array}{l}\text { ICU patients } \\
n=259\end{array}$ & Parallel & 5 & $\begin{array}{l}\text { Start: } 30 \mathrm{cc} / \mathrm{h} \text {; max: } 80 \mathrm{cc} / \mathrm{h} \text {; increase } \\
\text { or decrease according to GRV }\end{array}$ & NGT/ OGT & $\begin{array}{l}\text { EN (Nutrison Energy) + Synbiotic } 2000 \\
\text { FORTE / twice a day/ to the earliest of the } \\
\text { following time point: } 28 \text { days after } \\
\text { admission, death or discharge }\end{array}$ & $\begin{array}{l}\text { EN (Nutrison } \\
\text { Energy) }+ \text { placebo }\end{array}$ \\
\hline $\begin{array}{l}\text { Frohmader } \\
\text { et al., } 2010 \\
{[22]}\end{array}$ & $\begin{array}{l}\text { ICU patients } \\
n=45\end{array}$ & Parallel & 5 & $\begin{array}{l}\text { Start: first } 24 \mathrm{~h}, 20 \mathrm{cc} / \mathrm{h} \text {; increase: } 20 \mathrm{cc} / \\
\text { 4h to target. Target: } 25-35 \mathrm{kcal} / \mathrm{kg}\end{array}$ & $\begin{array}{l}\text { NGT/ OGT/ } \\
\text { nasojejunostomy }\end{array}$ & $\begin{array}{l}\text { Fiber-free EN+ probiotic (VSL\#3) /twice a } \\
\text { day/ mean of } 11.9 \text { days }\end{array}$ & $\begin{array}{l}\text { Fiber-free EN+ } \\
\text { placebo }\end{array}$ \\
\hline $\begin{array}{l}\text { Barraud } \\
\text { et al., } 2010 \\
{[23]}\end{array}$ & $\begin{array}{l}\text { ICU patients } \\
\text { with MV } \\
n=167\end{array}$ & Parallel & 5 & $\begin{array}{l}\text { Starting in the first } 24 \mathrm{~h}, 10 \mathrm{kcal} / \mathrm{kg} \text {, } \\
\text { increase to } 30-35 \mathrm{kcal} / \mathrm{kg}\end{array}$ & NGT & $\begin{array}{l}\text { EN + multi-strain probiotic (Ergyphilus)/ } \\
\text { once a day/ until successful weaning } \\
\text { (maximum of } 28 \text { days) }\end{array}$ & $\mathrm{EN}+$ placebo \\
\hline $\begin{array}{l}\text { Morrow } \\
\text { et al., } 2010 \\
{[24]}\end{array}$ & $\begin{array}{l}\text { ICU patients } \\
\text { with MV } \\
n=167\end{array}$ & Parallel & 5 & NR & NGT & $\begin{array}{l}\mathrm{EN}+\text { probiotic (Lactobacillus rhamnosus } \\
\mathrm{GG}) / \text { twice a day/ }\end{array}$ & $\begin{array}{l}\text { EN+ inulin-based } \\
\text { placebo }\end{array}$ \\
\hline $\begin{array}{l}\text { Ferrie and } \\
\text { Daley, } 2011 \\
{[25]}\end{array}$ & $\begin{array}{l}\text { ICU patients } \\
\text { with } \\
\text { diarrhea } \\
n=36\end{array}$ & Parallel & 5 & NR & Gastric tube & $\begin{array}{l}\text { Fiber containing EN+ probiotic (inulin- } \\
\text { based Lactobacillus GG)/twice a day/ } 7 \\
\text { days }\end{array}$ & $\begin{array}{l}\text { Fiber containing } \\
\text { EN+ placebo } \\
\text { (inulin) }\end{array}$ \\
\hline $\begin{array}{l}\text { Sanaie } \\
\text { et al., } 2014 \\
{[26]}\end{array}$ & $\begin{array}{l}\text { ICU patient } \\
n=40\end{array}$ & Parallel & 5 & $\begin{array}{l}\text { Start in first } 24 \mathrm{~h}, 25 \mathrm{cc} / \mathrm{h} \text {; increase } \\
25 \mathrm{cc} / 4 \mathrm{~h} \text { to target. Target: } 25-30 \mathrm{kcal} / \\
\mathrm{kg}\end{array}$ & NGT & $\begin{array}{l}\text { Fiber containing EN+ probiotic (VSL\#3)/ } \\
\text { twice daily/ } 7 \text { days }\end{array}$ & $\begin{array}{l}\text { Fiber containing } \\
\text { EN+ placebo }\end{array}$ \\
\hline $\begin{array}{l}\text { Majid et al., } \\
2014 \text { [27] }\end{array}$ & $\begin{array}{l}\text { ICU patients } \\
n=22\end{array}$ & Parallel & 5 & $\begin{array}{l}\text { Energy estimation based on } \\
\text { Schofield equation }\end{array}$ & NGT & $\begin{array}{l}\text { Fiber containing EN+ additional } \\
\text { oligofructose/inulin/ } 7 g \text { per day/ 7days }\end{array}$ & $\begin{array}{l}\text { Fiber containing } \\
\text { EN+ placebo }\end{array}$ \\
\hline $\begin{array}{l}\text { Malik et al., } \\
2016[28]\end{array}$ & $\begin{array}{l}\text { ICU patients } \\
n=60\end{array}$ & Parallel & 5 & $\begin{array}{l}25 \mathrm{kcal} / \mathrm{kg} \text {. start in first } 24-48 \mathrm{~h} \text {, with } \\
\text { GRV management }\end{array}$ & NGT & $\begin{array}{l}\text { EN+ multi-strain probiotic/ twice a day/ } 7 \\
\text { days }\end{array}$ & EN+ placebo \\
\hline $\begin{array}{l}\text { Fazilaty } \\
\text { et al., } 2018 \\
\text { [29] }\end{array}$ & $\begin{array}{l}\text { Multiple } \\
\text { trauma ICU } \\
\text { patients } \\
n=40\end{array}$ & Parallel & 5 & Goal: $25-30 \mathrm{kcal} / \mathrm{kg}, 75 \%$ in the $48 \mathrm{~h}$ & NGT & $\begin{array}{l}\text { EN+ prebiotic (oat } \beta \text {-glucan)/ 3g per day/ } \\
21 \text { days }\end{array}$ & $\begin{array}{l}\text { EN+ placebo } \\
\text { (maltodextrin) }\end{array}$ \\
\hline $\begin{array}{l}\text { Shimizu } \\
\text { et al., } 2018 \\
\text { [30] }\end{array}$ & $\begin{array}{l}\text { Septic ICU } \\
\text { patients with } \\
\text { MV } \\
n=72\end{array}$ & Parallel & 3 & $\begin{array}{l}\text { Start: } 20 \mathrm{cc} / \mathrm{h} \text {; increase: } 20 \mathrm{cc} / \mathrm{h} / \text { day to } \\
\text { target. Target: } 25-30 \mathrm{kcal} / \mathrm{kg}\end{array}$ & NGT & $\begin{array}{l}\text { EN +multi-strain probiotic (Yakult BL } \\
\text { Seichoyaku) } 3 \mathrm{~g} \text { per day+ prebiotic } \\
\text { (galactooligosaccharides) } 10 \mathrm{~g} \text { per day/ } \\
\text { until EN stop }\end{array}$ & EN \\
\hline $\begin{array}{l}\text { Tuncay } \\
\text { et al., } 2018 \\
{[31]}\end{array}$ & $\begin{array}{l}\text { Neurocritical } \\
\text { care patients } \\
n=46\end{array}$ & Parallel & 1 & $\begin{array}{l}\text { Start: } 10 \mathrm{cc} / \mathrm{h} \text {; increase: } 10 \mathrm{cc} / 8 \mathrm{~h} \text { till } \\
20 \mathrm{cc} / \mathrm{h} \text {; requirement: } \text { Schofield } \\
\text { equation+stress factor+activity } \\
\text { factor+ ventilator support+fever+TEF }\end{array}$ & $\begin{array}{l}\text { Nasofeeding, } \\
\text { gastrostomy/ } \\
\text { PEG }\end{array}$ & EN with prebiotic content/ 21 days & EN \\
\hline
\end{tabular}

NR Not reported; NGT Nasogastric tube; EN Enteral nutrition; ICU Intensive care unit; OGT Orogastric tube; GRV Gastric residual volume; VSL\#3, a single daily high dose probiotic preparation

Based on the findings of the studies and the harvest plot, it can be concluded that majority of the studies indicated a non-significant effect for pre, pro, or synbiotics administration on energy intake and feed volume.

\section{Effect on target calorie achievement}

Four trials assessed the effect of prebiotics or probiotics on the prevalence of target calorie achievement or time to receive the target calorie. 


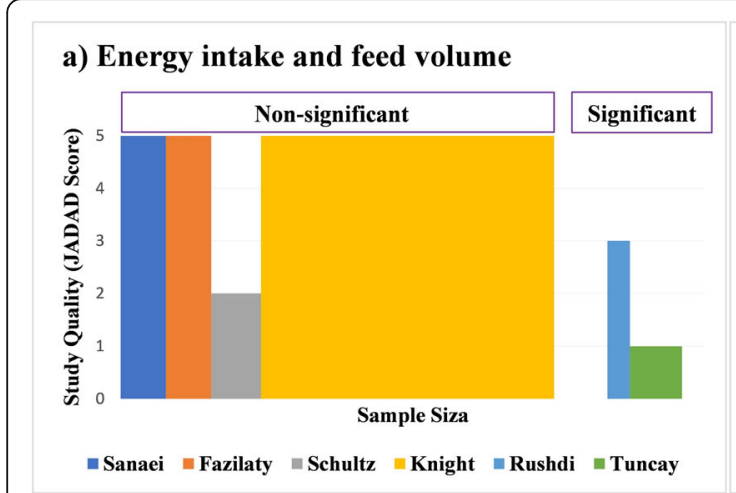

b) Diarrhea

\section{c) Achieving target calorie}
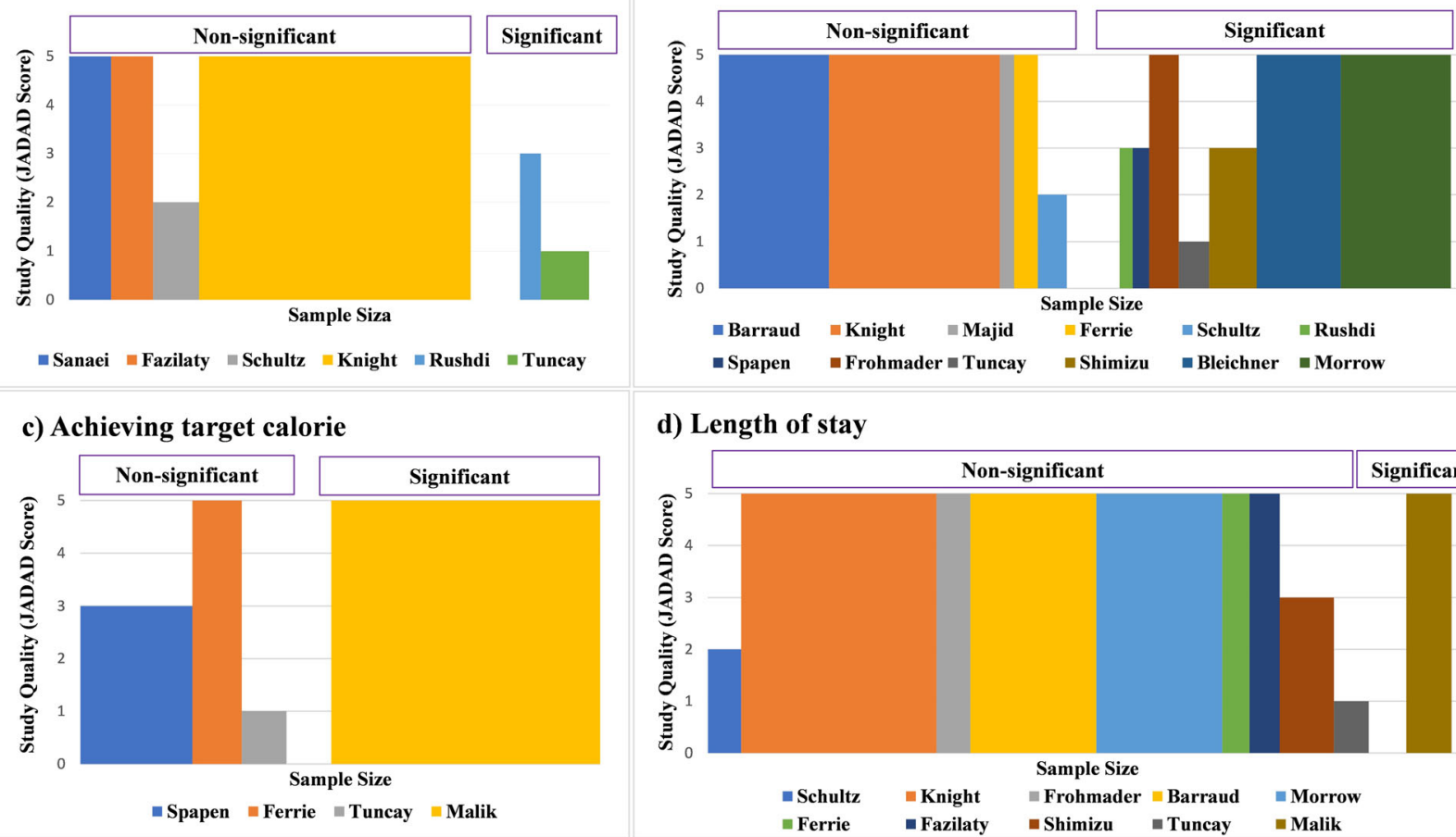

d) Length of stay

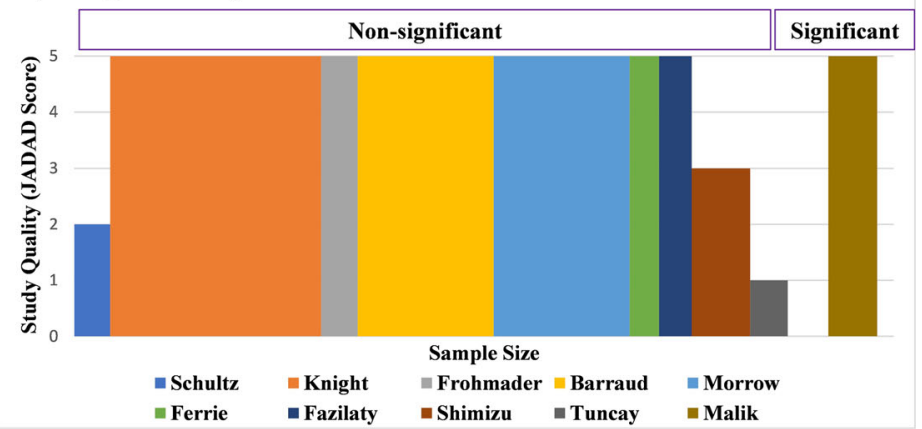

Fig. 2 Harvest plot for the difference between intervention and control groups in terms of achieving target calorie (a), energy intake and feed volume (b), length of stay (c), and diarrhea (d)

\section{Prebiotics}

In a trial conducted in 2001, severe sepsis or septic shock patients were randomly assigned to receive EN supplemented with partially hydrolyzed guar or fiberfree EN. All patients were on mechanical ventilation, antibiotics, and catecholamine therapy. The time to reach the preconceived protein/calorie goals was $5 \pm 3$ days in the prebiotic and $6 \pm 3$ days in the control group. The difference was not statistically significant [25]. In another trial conducted by Tuncay et al., the prevalence of target dose achievement in 21 days intervention was $95.7 \%$ in prebiotic supplemented and $78.3 \%$ in standard EN groups. The difference was not statistically significant $(p=0.19)[22]$.

\section{Probiotics}

Malik et al. investigated the effect of 7-day microbial cell preparation administration on the return of gut function. Time to return to normal gut function was defined as the time taken to receive a minimum of $80 \%$ of the estimated calorie for a consecutive 48 -h period. They reported that patients in the treatment group achieved a faster return of gut function $(3 \pm 1.75$ days vs. $7 \pm 1.7$ days, $p<0.001)$ [26]. Ferrie et al. also investigated the effect of Lactobacillus rhamnosus GG on feeding intolerance in critically ill patients with established diarrhea. The frequency of patients with feeding intolerance (tolerate less than $80 \%$ of calorie goal for two consecutive days) was $11.1 \%$ in the probiotic group and $16.6 \%$ in the control group ( $p=0.63$ ) [27].

Based on the findings of the studies and the harvest plot, it can be concluded that majority of the studies indicated a non-significant effect for pre, pro, or synbiotics administration on target calorie achievement but the only one study that reported a significant finding had a large sample size. Therefore, it may outweigh the findings of the non-significant studies. Thus, the findings of the current studies are inconclusive.

\section{Effect on diarrhea \\ Prebiotics}

Schultz et al. investigated the effect of pectin on the prevalence of diarrhea in a critical care setting. Diarrhea was more prevalent in the fiber-free/placebo group compared to the fiber-free/pectin group (36\% vs. 9\%, $p=$ 0.31 ). Diarrhea was also more prevalent in the fiber/ placebo than fiber/pectin group; however, the differences were not statistically significant $(55 \%$ vs. $9 \%, p=0.06$ ) [19]. Majid et al. also demonstrated that fiber-enriched EN with additional prebiotic had no significant effect on the prevalence of diarrhea. The prevalence of having at least 1 day of diarrhea was $92 \%$ in the prebiotic and $90 \%$ in the placebo group $(p=0.99)$. The number of days of diarrhea was $3.8 \pm 3.5$ in the placebo and $3.9 \pm 4.1$ in the 
prebiotic group $(p=0.94)$ [28]. Tuncay et al. reported that administration of prebiotic-enriched EN was associated with a significant tendency toward lower prevalence $(8.7 \%$ vs. $56.5 \%)$ and faster amelioration of diarrhea (none vs. 52.2\% diarrhea prevalence on day 7) [22].

In another trial, the prevalence of having at least 1 day of diarrhea was $46.1 \%$ in the prebiotic and $91.7 \%$ in the placebo group $(p=0.03)$. Further, the mean frequency of days of having diarrhea was significantly lower in the fiber group. Besides, in the fiber group, diarrhea occurred in $10.8 \%$ of feeding days, compared to $31.5 \%$ in the controls $(p<0.001)$ [25].

Rushdi et al. also investigated the effect of soluble guar gum on the number of liquid stools during the four days of intervention. The number of liquid stools was significantly lower at day 4 compared to day 1 in the intervention group, while it was significantly higher in the control group. The number of liquid stools on the fourth day was $1.2 \pm 0.7$ in the intervention group, compared to $2.1 \pm 0.8$ in the control group $(p<0.01)[20]$.

\section{Probiotics}

In the study by Bleichner et al., 128 critically ill patients were randomized to receive Saccharomyces Boulardii or placebo capsules. The prevalence of diarrhea was not significantly different between the two groups. However, treatment with $S$. boulardii reduced the mean frequency of diarrhea days per feeding days from 18.9 to $14.2 \%(p=0.006)$. The number of days with diarrhea was also significantly lower in the probiotic group $(p<0.001)$ [29]. Barraud et al. also investigated the effect of probiotic administration on the prevalence of diarrhea. They demonstrated no significant effect of probiotic therapy on diarrhea prevalence (55.2\% vs. $52.5 \%, p=0.72)$ [30]. In another RCT, Morrow et al. demonstrated that probiotic administration had no significant effect on the incidence of ICUassociated diarrhea. However, the number of days with ICU-associated diarrhea was significantly higher in the placebo group compared to the probiotic group (5.9 \pm 3.8 vs. $4.1 \pm 3.7, p=0.03)$ [31]. Another trial in 2010 examined the effect of probiotic VSL\#3 on diarrhea among 45 critically ill patients. The mean frequency of liquid stool in the probiotic and placebo groups was $0.53 \pm 0.54$ and $1.05 \pm 1.08$ episodes per patient per day, respectively $(p=0.03)$ [32]. Ferrie et al. also reported that critically ill patients who received probiotic had more diarrhea episodes compared to the control group, although the difference was not statistically significant. Diarrhea days in the 14-day study period was $7.22 \pm 3.63$ in the probiotic and $5.72 \pm$ 2.88 in the synbiotic group $(p=0.17)$ [27].

\section{Synbiotics}

Knight et al. reported the overall prevalence of diarrhea to be $5 \%$ in the synbiotic group, and $7 \%$ in the controls $(p=0.59)$ [24]. Shimizu et al. also investigated the effect of daily synbiotic therapy on infectious complications, including enteritis in the intensive care unit. Enteritis was defined as acute onset of continuous liquid stool for more than $12 \mathrm{~h}$. The results showed that the incidence of enteritis was significantly lower in the synbiotic group (6.3\% vs. $27.0 \% ; p<0.05)$ [33].

Based on the findings of the studies and the harvest plot, it can be concluded that majority of the studies indicated a significant effect for pre, pro, or synbiotics on diarrhea in terms of duration or frequency.

\section{Effect on length of stay}

The effect of pre, pro, or synbiotics on ICU and hospital LOS was reported in 10 and 5 trials, respectively (Table 3). Malik et al. demonstrated that probiotic administration was associated with significantly lower ICU LOS [26]. Other studies found no significant difference between groups, regarding ICU or hospital LOS $[19,21$, 22, 24, 27, 30-33].

Based on the findings of the studies and the harvest plot, it can be concluded that majority of the studies indicated a non-significant effect for pre, pro, or synbiotics administration on length of stay.

\section{Discussion}

In this systematic review, 15 randomized controlled trials were reviewed to determine the potential of pre, pro, or synbiotics administration to improve enteral feeding tolerance in tube-fed critically ill patients. Gut microbiota is a key regulator of gut function, host metabolism, and appetite. Microbial metabolites, including SCFAs, bile acids, and various neuroactive agents, interact with the GI tract and peripheral tissue through affecting the enteric nervous system and central appetite pathways or altering bile acid signaling [34]. These effects result in changes in gastric motility and emptying [35, 36], which may reduce enteral feeding intolerance. Besides, gut microbiota can influence intestinal barrier function and modulate the immune system, thus indirectly affect metabolism and eating behavior [16].

\section{Effect on energy intake or feed volume}

We found six studies that evaluated the effect of pre, pro, or synbiotics on enteral feeding volume or energy intake. Considering the application of probiotics or synbiotics, no significant effect was reported. Only 2 of 4 studies, which used prebiotics (one soluble guar gum for 4 days and the other FOS for 21 days) in the intervention group, found significant beneficial effects [20, 22]. It should be noted that in both of these studies, patients in 
Table 3 Reported feeding tolerance-related outcomes in RCTs evaluating the effect of pre, pro, or synbiotics on feeding tolerance of enterally fed critically ill patients

\begin{tabular}{|c|c|c|c|c|c|c|c|c|}
\hline \multirow[t]{2}{*}{ Study } & \multicolumn{2}{|l|}{ Energy intake } & \multicolumn{2}{|c|}{$\begin{array}{l}\text { Achieving the target } \\
\text { calorie }\end{array}$} & \multicolumn{2}{|l|}{ Diarrhea } & \multicolumn{2}{|l|}{ Length of stay } \\
\hline & Intervention & Control & Intervention & Control & Intervention & Control & Intervention & Control \\
\hline $\begin{array}{l}\text { Bleichner } \\
\text { et al., } 1997 \\
\text { [17] }\end{array}$ & NR & NR & NR & NR & $\begin{array}{l}\text { Prevalence: } 18 / 64 \\
\text { (24\%) } \\
\text { Days w/ diarrhea per } \\
\text { feeding days: } 14.2 \%\end{array}$ & $\begin{array}{l}\text { Prevalence: } 24 / 64 \text { (38\%) } \\
\text { Days w/ diarrhea per } \\
\text { feeding days: } 18.9 \%\end{array}$ & NR & NR \\
\hline $\begin{array}{l}\text { Schultz } \\
\text { et al., } 2000 \\
{[18]}\end{array}$ & Mean $^{a}$ & Mean $^{a}$ & NR & NR & Prevalence: 1/11 (9\%) & Prevalence: 4/11 (36\%) & $\begin{array}{l}\text { Hospital: } 34 \pm \\
\text { 14.7 } \\
\text { ICU: } 28 \pm 14.6\end{array}$ & $\begin{array}{l}\text { Hospital: } \\
24.4 \pm 9 \\
\text { ICU: } 17.2 \pm 8.2\end{array}$ \\
\hline $\begin{array}{l}\text { Spapen } \\
\text { et al., } 2001 \\
{[19]}\end{array}$ & NR & NR & $\begin{array}{l}\text { Time to: } 5 \pm 3 \\
\text { days }\end{array}$ & $\begin{array}{l}\text { Time to: } \\
6 \pm 3 \text { days }\end{array}$ & $\begin{array}{l}\text { Prevalence: } 6 / 13 \text { (46\%) } \\
\text { Days } w \text { diarrhea per } \\
\text { feeding days: } 16 / \\
148(10.8 \%)\end{array}$ & $\begin{array}{l}\text { Prevalence: } 11 / 12(92 \%) \\
\text { Days w diarrhea per } \\
\text { feeding days: } 46 / 146 \\
(31.5 \%)\end{array}$ & NR & NR \\
\hline $\begin{array}{l}\text { Rushdi et al., } \\
2004 \text { [20] }\end{array}$ & Days 1-4 & $\begin{array}{l}\text { Days 1- } \\
4\end{array}$ & NR & $N R$ & Liquid stools day 1-4 & Liquid stools days 1-4 & NR & NR \\
\hline $\begin{array}{l}\text { Knight et al.. } \\
2009 \text { [21] }\end{array}$ & Days 1-7 & $\begin{array}{l}\text { Days 1- } \\
7\end{array}$ & NR & $N R$ & Prevalence: 7/130 (5\%) & Prevalence: 9/129 (7\%) & ICU: 6 (3-11) & ICU: 7 (3-14) \\
\hline $\begin{array}{l}\text { Frohmader } \\
\text { et al., } 2010 \\
{[22]}\end{array}$ & NR & NR & NR & NR & $\begin{array}{l}\text { Frequency of liquid } \\
\text { stools: } 0.53 \pm 0.54\end{array}$ & $\begin{array}{l}\text { Frequency of liquid } \\
\text { stools: } 1.05 \pm 1.08\end{array}$ & ICU: $7.3 \pm 5.7$ & ICU: $8.1 \pm 4$ \\
\hline $\begin{array}{l}\text { Barraud } \\
\text { et al., } 2010 \\
{[23]}\end{array}$ & NR & NR & NR & NR & Prevalence: 48/87(55.2) & Prevalence: 42/80(52.5) & $\begin{array}{l}\text { Hospital: } \\
26.6 \pm 22.3 \\
\text { ICU: } 18.7 \pm 12.3\end{array}$ & $\begin{array}{l}\text { Hospital: } \\
28.9 \pm 26.4 \\
\text { ICU: } 20.2 \pm 20.8\end{array}$ \\
\hline $\begin{array}{l}\text { Morrow } \\
\text { et al., } 2010 \\
\text { [24] }\end{array}$ & NR & NR & NR & NR & $\begin{array}{l}\text { Prevalence: 44/70(62.9) } \\
\text { Days w/ diarrhea: } 5.9 \pm \\
3.8\end{array}$ & $\begin{array}{l}\text { Prevalence: 42/68(61.8) } \\
\text { Days w/ diarrhea: } 4.1 \pm \\
3.7\end{array}$ & $\begin{array}{l}\text { Hospital: } \\
21.4 \pm 14.9 \\
\text { ICU: } 14.8 \pm 11.8\end{array}$ & $\begin{array}{l}\text { Hospital: } \\
21.7 \pm 17.4 \\
\text { ICU: } 14.6 \pm 11.6\end{array}$ \\
\hline $\begin{array}{l}\text { Ferrie and } \\
\text { Daley, } 2011 \\
{[25]}\end{array}$ & NR & NR & $\begin{array}{l}\text { Prevalence } \\
16 / 18 \text { (88.8) }\end{array}$ & $\begin{array}{l}\text { Prevalence } \\
15 / \\
18(83.33)\end{array}$ & $\begin{array}{l}\text { Diarrhea duration: } \\
7.22 \pm 3.63 \\
\text { Loose stool per day: } \\
3.14 \pm 1.23\end{array}$ & $\begin{array}{l}\text { Diarrhea duration: } \\
5.72 \pm 2.88 \\
\text { Loose stool per day: } 3 \pm \\
1.2\end{array}$ & $\begin{array}{l}\text { Hospital: } \\
54.5 \pm 31.26 \\
\text { ICU: } 32.04 \pm \\
24.46\end{array}$ & $\begin{array}{l}\text { Hospital: } \\
59.04 \pm 33.92 \\
\text { ICU: } 29.75 \pm \\
18.81\end{array}$ \\
\hline $\begin{array}{l}\text { Sanaie et al., } \\
2014 \text { [26] }\end{array}$ & Mean $^{a}$ & Mean $^{a}$ & NR & NR & NR & NR & NR & NR \\
\hline $\begin{array}{l}\text { Majid et al., } \\
2014 \text { [27] }\end{array}$ & NR & NR & NR & NR & $\begin{array}{l}\text { Prevalence: } 11 / 12(92) \\
\text { Days w/ diarrhea: } 3.9 \pm \\
4.1\end{array}$ & $\begin{array}{l}\text { Prevalence: } 9 / 10(90) \\
\text { Days w/ diarrhea: } 3.8 \pm \\
3.5\end{array}$ & NR & NR \\
\hline $\begin{array}{l}\text { Malik et al., } \\
2016 \text { [28] }\end{array}$ & NR & NR & $\begin{array}{l}\text { Time to: } 3 \pm \\
1.75 \text { days }\end{array}$ & $\begin{array}{l}\text { Time to: } \\
7 \pm 1.7 \text { days }\end{array}$ & NR & NR & ICU: $10.9 \pm 3.9$ & ICU: $15.8 \pm 7.8$ \\
\hline $\begin{array}{l}\text { Fazilaty } \\
\text { et al., } 2018 \\
{[29]}\end{array}$ & Mean $^{a}$ & Mean $^{a}$ & NR & NR & NR & NR & ICU: $27.55 \pm 7.8$ & ICU: $31.2 \pm 15.8$ \\
\hline $\begin{array}{l}\text { Shimizu } \\
\text { et al., } 2018 \\
\text { [30] }\end{array}$ & NR & NR & NR & NR & $\begin{array}{l}\text { Incidence of enteritis: } \\
2 / 35(6.3)\end{array}$ & $\begin{array}{l}\text { Incidence of enteritis: } \\
\text { 10/37(27) }\end{array}$ & $\begin{array}{l}\text { ICU: } 23(13- \\
43)\end{array}$ & $\begin{array}{l}\text { ICU: } 28 \text { (17- } \\
45)\end{array}$ \\
\hline $\begin{array}{l}\text { Tuncay et al., } \\
2018 \text { [31] }\end{array}$ & $\begin{array}{l}\text { Days } 1 \text { and } \\
21\end{array}$ & $\begin{array}{l}\text { Days } 1 \\
\text { and } 21\end{array}$ & $\begin{array}{l}\text { Prevalence } \\
22(95.7)\end{array}$ & $\begin{array}{l}\text { Prevalence } \\
18(78.3)\end{array}$ & Prevalence: $8.7 \%$ & Prevalence: $56.5 \%$ & $\begin{array}{l}\text { Hospital stay } \\
<40 \text { days: } \\
56.6 \% \\
\text { Hospital stay } \\
\geq 41 \text { days: } \\
43.4 \% \\
\text { ICU stay }<40 \\
\text { days: } 69.5 \% \\
\text { ICU stay } \geq 41 \\
\text { days: } 43.5 \%\end{array}$ & $\begin{array}{l}\text { Hospital stay } \\
\text { <40 days: } \\
60.9 \% \\
\text { Hospital stay } \\
\geq 41 \text { days: } \\
39.1 \% \\
\text { ICU stay <40 } \\
\text { days: } 69.5 \% \\
\text { ICU stay } \geq 41 \\
\text { days: } 30.4 \%\end{array}$ \\
\hline
\end{tabular}


the intervention group received significantly more volume and energy on the first day. Therefore, it seems that the significant difference between the two groups in terms of received feed volume and energy at the end of the study may not be merely attributed to the effect of prebiotics.

\section{Effect on target calorie achievement}

Four trials evaluated the effect of pre or probiotics on frequency or time to achieve the target calorie. All studies but one found no significant effect. In this study, probiotic administration for seven consecutive days was associated with a significantly faster return of the gut function [26]. The included studies were heterogeneous in population features, intervention, duration, eligibility criteria, and EN protocol. Thus, the conflicting results may be attributed to these factors. It is also believed that the beneficial effect of probiotics or synbiotics could be highly strain-specific.

\section{Effect on diarrhea}

In the critical care setting, diarrhea is the most common gastrointestinal complication of EN [37], which may result in several unfavorable clinical conditions including enteral nutrition cessation and exacerbation of undernutrition [22]. Factors that contribute to the pathogenesis of diarrhea include altered physiological responses due to EN, antibiotics administration, and altered gut microbiota function [38]. Therefore, gut microbiota manipulation may be an approach for the prevention and management of diarrhea in the critical care setting. For example, gut microbiota manipulation can reverse abnormal colonic water secretion by SCFAs production [39], alter colonic motor activity [40], and interfere with pathogen colonization in the gut, which protects against diarrhea [38].

The effect of prebiotics on diarrhea was evaluated in five clinical trials $[19,20,22,25,28]$. Four studies investigated the effect of prebiotic on the prevalence of diarrhea. While two studies found a significant $[22,25]$ and one a non-significant decrease [19], the other reported a non-significant increase [28]. The number of days of diarrhea was also investigated in two studies, one of which reported a significant decrease [25], while the other found a non-significant increase [28]. The number of liquid stools was also reported to be lower in the prebiotic group in one trial [21].

It should be noticed that water-soluble fiber like pectin or guar gum exhibits antidiarrheal effect by two mechanisms: (1) production of SCFAs and maintaining gut microbiota homeostasis or (2) reuptake of water and electrolytes [41]. The beneficial effect of water-soluble fibers on SCFAs production is well documented in noncritically ill patients and healthy subjects, but it is not clearly observed in critically ill patients [41]. So, the positive effect of water-soluble fibers in the mentioned studies may be attributed to the increased reuptake of water and electrolytes, not necessarily acting as prebiotics.

Regarding the effect of probiotics on the incidence of diarrhea, two studies reported a trend towards reduced diarrhea incidence in the probiotic group [29, 31], and one reported a non-significant increase [30]. The effect of probiotic administration on diarrhea days was demonstrated in three of the included trials. Two of them reported a significant decrease in diarrhea duration [29, 31], while one reported a non-significant increase [27]. In the probiotic group, the number of liquid stools per patient per day was reported to be significantly lower in one study [32] but loose stools were non-significantly more in another study [27].

A non-significant decrease in the prevalence of diarrhea [24] and a significant decrease in the incidence of enteritis [33] were reported to be associated with synbiotic administration.

\section{Effect on length of stay}

All but one study found no beneficial effects for gut microbiota manipulation on clinical endpoints, including LOS in hospital and ICU. A recent systematic review and meta-analysis by Manzanares et al. also showed that despite the beneficial effects of probiotic and synbiotic administration on overall infections and ventilatorassociated pneumonia, these agents had no significant effect on LOS in hospital or ICU [42].

To the best of our knowledge, this systematic review was the first study to review the effect of pre, pro, and synbiotics on feeding tolerance in enterally fed critically ill patients. As we assessed relevant outcomes in a heterogeneous ICU population, our results could be attributed to a broad spectrum of critically ill patients with sepsis, trauma, or other medical conditions. Although, the inclusion of diverse patient groups in this systematic review may be considered as a limitation for interpretation of the results. There was also great diversity in the type of administered prebiotic or probiotic strains, duration of treatment, and dose. This heterogeneity also made it impossible to quantitatively evaluate the results. Furthermore, most of the included studies reported the energy intake or feeding tolerance as a secondary outcome, not mentioning the EN protocols, while the reported EN protocols were heterogeneous in other studies.

\section{Conclusion}

Overall, the heterogeneity in studied product format, ICU patient populations, and study designs make it difficult to draw any general conclusion on the effect of pre, 
pro, or synbiotics on feeding tolerance of critically ill tube-fed patients. We suggest more new well-designed trials that assess feeding tolerance as a primary endpoint with a unified definition and an invariable enteral nutrition protocol that would make it possible to compare the obtained results. We have recently designed an RCT in which the main purpose is to determine the effect of synbiotics on feeding tolerance and energy homeostasis of critically ill adult patients [43]. New trials should aim to demonstrate the beneficial composition of supplements, dose, and duration to have beneficial effects. There is, moreover, a need to conduct studies that clearly establish the molecular mechanisms by which gut microbiota manipulation is attributed to feeding tolerance in critically ill patients.

\section{Abbreviations}

CCK: Cholecystokinin; EN: Enteral nutrition; FOS: Fructo-oligosaccharide; Gl: Gastrointestinal; GRV: Gastric residual volume; ICU: Intensive care unit; LOS: Length of stay; PICOS: Population, intervention, comparison, outcome, and study design; PRISMA: Preferred reporting items for systematic reviews and meta-analysis; PYY: Peptide YY; RCT: Randomized controlled trials; SCFAs: Short-chain fatty acids

\section{Supplementary Information}

The online version contains supplementary material available at https://doi. org/10.1186/s13643-021-01633-5.

Additional file 1:. Preferred Reporting Items for Systematic Reviews and Meta-Analysis (PRISMA) statement

\section{Acknowledgements}

The support provided by Mashhad University of Medical Sciences (MUMS) to conduct this study is highly acknowledged. We also appreciate the support of the Clinical Research Development Unit of Akbar Hospital.

\section{Authors' contributions}

NS: conceptualization, methodology, investigation, writing the original draft AJE: methodology, investigation, review, and editing. AS: review and editing, supervision. MKR: methodology, formal analysis. RR: conceptualization, review and editing. MS: project administration, supervision. The authors read and approved the final manuscript.

\section{Funding}

This research is funded by vice chancellery for research of Mashhad University of Medical Sciences (MUMS)

\section{Availability of data and materials}

The datasets generated and/or analyzed during the current study are not publicly available, but may be available from the corresponding author on reasonable request.

\section{Declarations}

Ethics approval and consent to participate

Not applicable

\section{Consent for publication}

Not applicable

\section{Competing interests}

No conflict of interest has been declared by the authors.

\section{Author details}

${ }^{1}$ Department of Nutrition, Medical School, Mashhad University of Medical Sciences, Mashhad, Iran. ${ }^{2}$ Department of Anesthesiology, Mashhad University of Medical Sciences, Mashhad, Iran. ${ }^{3}$ Department of Community Medicine, Medical School, Mashhad University of Medical Sciences, Mashhad, Iran. ${ }^{4}$ Metabolic Syndrome Research Center, Mashhad University of Medical Sciences, Mashhad, Iran.

Received: 29 April 2020 Accepted: 11 March 2021

Published online: 02 April 2021

\section{References}

1. Sharma K, Mogensen KM, Robinson MK. Pathophysiology of critical illness and role of nutrition. Nutr Clin Pract. 2019;34(1):12-22. https://doi.org/10.1 002/ncp.10232.

2. Hoffer $\amalg$, Bistrian BR. Nutrition in critical illness: a current conundrum. F1000Res. 2016:5:2531. https://doi.org/10.12688/f1000research.9278.1.

3. Heinonen T, Ferrie S, Ferguson C. Gut function in the intensive care unit What is "normal"? Aust Crit Care. 2020;33(2):151-4. https://doi.org/10.1016/j.a ucc.2018.12.007.

4. Moron R, Galvez J, Colmenero M, Anderson P, Cabeza J, Rodriguez-Cabezas ME. The importance of the microbiome in critically ill patients: role of nutrition. Nutrients. 2019;11(12):3002. https://doi.org/10.3390/nu11123002.

5. Kitsios GD, Morowitz MJ, Dickson RP, Huffnagle GB, McVerry BJ, Morris A Dysbiosis in the intensive care unit: Microbiome science coming to the bedside. J Crit Care. 2017:38:84-91. https://doi.org/10.1016/j.jcrc.2016.09.029.

6. Blaser AR, Starkopf J, Alhazzani W, Berger MM, Casaer MP, Deane AM, et al. Early enteral nutrition in critically ill patients: ESICM clinical practice guidelines. Intensive Care Med. 2017;43(3):380-98. https://doi.org/10.1007/ s00134-016-4665-0.

7. McClave SA, Gualdoni J, Nagengast A, Marsano LS, Bandy K, Martindale RG. Gastrointestinal dysfunction and feeding intolerance in critical illness: do we need an objective scoring system? Curr Gastroenterol Rep. 2020;22(1):1. https://doi.org/10.1007/s11894-019-0736-z.

8. Blaser AR, Starkopf J, Kirsimägi Ü, Deane A. Definition, prevalence, and outcome of feeding intolerance in intensive care: a systematic review and meta-analysis. Acta Anaesthesiolog Scand. 2014;58(8):914-22. https://doi. org/10.1111/aas.12302

9. Chen W-T, Du M-J, Chen Y-Z, Yuan D-Q. Factors influencing feeding intolerance in critically ill patients during enteral nutrition. Int J Clin Exp Med. 2019:12(7):7999-8003.

10. Roberfroid MB. Prebiotics and synbiotics: concepts and nutritional properties. Br J Nutr. 1998:80(4):S197-202.

11. Verdu E. Probiotics effects on gastrointestinal function: beyond the gut? Neurogastroenterol Motil. 2009;21(5):477-80. https://doi.org/10.1111/j.1365-2 982.2009.01297.x.

12. Distrutti $E$, Monaldi L, Ricci P, Fiorucci S. Gut microbiota role in irritable bowel syndrome: new therapeutic strategies. World J Gastroenterol. 2016; 22(7):2219-41. https://doi.org/10.3748/wjg.v22.i7.2219.

13. Butt RL, Volkoff H. Gut microbiota and energy homeostasis in fish. Front Endocrinol. 2019;10:9. https://doi.org/10.3389/fendo.2019.00009.

14. Cani PD, Geurts L, Matamoros S, Plovier H, Duparc T. Glucose metabolism: focus on gut microbiota, the endocannabinoid system and beyond. Diab Metab. 2014;40(4):246-57. https://doi.org/10.1016/j.diabet.2014.02.004.

15. Caricilli AM, Saad MJ. The role of gut microbiota on insulin resistance. Nutrients. 2013:5(3):829-51. https://doi.org/10.3390/nu5030829.

16. Spiljar M, Merkler D, Trajkovski M. The immune system bridges the gut microbiota with systemic energy homeostasis: focus on TLRs, mucosal barrier, and SCFAs. Front Immunol. 2017:8:1353. https://doi.org/10.3389/ fimmu.2017.01353.

17. Liberati A, Altman DG, Tetzlaff J, Mulrow C, Gøtzsche PC, loannidis JP, et al. The PRISMA statement for reporting systematic reviews and meta-analyses of studies that evaluate health care interventions: explanation and elaboration. PLoS Med. 2009;6(7):e1000100. https://doi.org/10.1371/journal. pmed. 1000100 .

18. Rikke BA, Wynes MW, Rozeboom LM, Barón AE, Hirsch FR. Independent validation test of the vote-counting strategy used to rank biomarkers from published studies. Biomark Med. 2015;9(8):751-61. https://doi.org/10.2217/ BMM.15.39. 
19. Schultz AA, Taylor BA-HR, Gillis DE, Wilkins M. Effects of pectin on diarrhea in critically ill tube-fed patients receiving antibiotics. Am J Crit Care. 2000; 9(6):403-11. https://doi.org/10.4037/ajcc2000.9.6.403.

20. Rushdi TA, Pichard C, Khater YH. Control of diarrhea by fiber-enriched diet in ICU patients on enteral nutrition: a prospective randomized controlled trial. Clin Nutr. 2004;23(6):1344-52.

21. Fazilaty Z, Chenari $H$, Shariatpanahi ZV. Effect of $\beta$-glucan on serum levels of IL-12, hs-CRP, and clinical outcomes in multiple-trauma patients: a prospective randomized study. Ulus Travma Acil Cerrahi Derg. 2018;24(4): 287-93. https://doi.org/10.5505/tjtes.2017.34514.

22. Tuncay P, Arpaci F, Doganay M, Erdem D, Sahna A, Ergun H, Atabey D. Use of standard enteral formula versus enteric formula with prebiotic content in nutrition therapy: a randomized controlled study among neuro-critical care patients. Clin Nutr ESPEN. 2018;25:26-36. https://doi.org/10.1016/j.clnesp.201 8.03.123.

23. Sanaie S, Ebrahimi-Mameghani M, Hamishehkar H, Mojtahedzadeh M, Mahmoodpoor A. Effect of a multispecies Probiotic on inflammatory markers in critically ill patients: a randomized, double-blind, placebocontrolled trial. J Res Med Sci. 2014;19(9):827-33.

24. Knight DJW, Gardiner D, Banks A, Snape SE, Weston VC, Bengmark S, Girling KJ. Effect of synbiotic therapy on the incidence of ventilator associated pneumonia in critically ill patients: a randomised, double-blind, placebocontrolled trial. Intensive Care Med. 2009;35(5):854-61. https://doi.org/10.1 007/s00134-008-1368-1.

25. Spapen H, Diltoer M, Van Malderen C, Opdenacker G, Suys E, Huyghens L. Soluble fiber reduces the incidence of diarrhea in septic patients receiving total enteral nutrition: a prospective, double-blind, randomized, and controlled trial. Clin Nutr. 2001;20(4):301-5. https://doi.org/10.1054/clnu.2 001.0399.

26. Malik AA, Rajandram R, Tah PC, Hakumat-Rai VR, Chin KF. Microbial cell preparation in enteral feeding in critically ill patients: A randomized, doubleblind, placebo-controlled clinical trial. J Crit Care. 2016;32:182-8. https://doi. org/10.1016/j.jcrc.2015.12.008.

27. Ferrie S, Daley M. Lactobacillus GG as treatment for diarrhea during enteral feeding in critical illness: randomized controlled trial. JPEN J Parenter Enteral Nutr. 2011;35(1):43-9. https://doi.org/10.1177/0148607110370705.

28. Majid HA, Cole J, Emery PW, Whelan K. Additional oligofructose/inulin does not increase faecal bifidobacteria in critically ill patients receiving enteral nutrition: a randomised controlled trial. Clin Nutr. 2014;33(6):966-72.

29. Bleichner G, Blehaut $H$, Mentec H, Moyse D. Saccharomyces boulardii prevents diarrhea in critically ill tube-fed patients. Intensive care medicine. 1997;23(5):517-23. https://doi.org/10.1007/s001340050367.

30. Barraud D, Blard C, Hein F, Marcon O, Cravoisy A, Nace L, et al. Probiotics in the critically ill patient: a double blind, randomized, placebo-controlled trial. Intensive Care Med. 2010;36(9):1540-7. https://doi.org/10.1007/s00134-010-1 927-0.

31. Morrow LE, Kollef MH, Casale TB. Probiotic prophylaxis of ventilatorassociated pneumonia: a blinded, randomized, controlled trial. Am J Respir Crit Care Med. 2010;182(8):1058-64. https://doi.org/10.1164/rccm.200912-1 8530C.

32. Frohmader TJ, Chaboyer WP, Robertson IK, Gowardman J. Decrease in frequency of liquid stool in enterally fed critically ill patients given the multispecies probiotic VSL\#3: a pilot trial. Am J Crit Care. 2010;19(3):e1-11. https://doi.org/10.4037/ajcc2010976.

33. Shimizu K, Yamada T, Ogura H, Mohri T, Kiguchi T, Fujimi S, Asahara T, Yamada T, Ojima M, Ikeda M, Shimazu T. Synbiotics modulate gut microbiota and reduce enteritis and ventilator-associated pneumonia in patients with sepsis: a randomized controlled trial. Crit Care. 2018;22(1):239. https://doi.org/10.1186/s13054-018-2167-x.

34. van de Wouw M, Schellekens H, Dinan TG, Cryan JF. Microbiota-gut-brain axis: modulator of host metabolism and appetite. J Nutr. 2017;147(5):72745. https://doi.org/10.3945/jn.116.240481.

35. Russo F, Clemente C, Linsalata M, Chiloiro M, Orlando A, Marconi E, Chimienti G, Riezzo G. Effects of a diet with inulin-enriched pasta on gut peptides and gastric emptying rates in healthy young volunteers. Eur J Nutr. 2011;50(4):271-7. https://doi.org/10.1007/s00394-010-0135-6.

36. Davani-Davari D, Negahdaripour M, Karimzadeh I, Seifan M, Mohkam M, Masoumi SJ, Berenjian A, Ghasemi Y. Prebiotics: definition, types, sources, mechanisms, and clinical applications. Foods. 2019;8(3):92. https://doi.org/1 0.3390/foods8030092.
37. Montejo JC. Enteral nutrition-related gastrointestinal complications in critically ill patients: a multicenter study. Crit Care Med. 1999;27(8):1447-53. https://doi.org/10.1097/00003246-199908000-00006.

38. Whelan K, Schneider SM. Mechanisms, prevention, and management of diarrhea in enteral nutrition. Curr Opin Gastroenterol. 2011;27(2):152-9. https://doi.org/10.1097/MOG.0b013e32834353cb.

39. Bowling TE, Raimundo AH, Grimble GK, Silk DBA. Reversal by short-chain fatty acids of colonic fluid secretion induced by enteral feeding. Lancet. 1993;342(8882):1266-8. https://doi.org/10.1016/0140-6736(93)92360-6.

40. Silk D, Walters E, Duncan H, Green C. The effect of a polymeric enteral formula supplemented with a mixture of six fibres on normal human bowel function and colonic motility. Clin Nutr. 2001;20(1):49-58. https://doi.org/1 $0.1054 /$ Inu.2000.0359.

41. Venegas-Borsellino C, Kwon M. Impact of Soluble Fiber in the Microbiome and Outcomes in Critically III Patients. Curr Nutr Rep. 2019;8(4):347-355. https://doi:10.1007/s13668-019-00299-9

42. Manzanares W, Langlois PL, Wischmeyer PE. Restoring the microbiome in critically ill patients: are probiotics our true friends when we are seriously ill? J Parenter Enteral Nutr. 2017;41(4):530-3. https://doi.org/10.1177/014860711 7700572.

43. Seifi N, Safarian M, Nematy M, Rezvani R, Khadem-Rezaian M, Sedaghat A. Effects of synbiotic supplementation on energy and macronutrients homeostasis and muscle wasting of critical care patients: study protocol and a review of previous studies. Trials. 2020;21(1):221.https://doi:10.1186/ s13063-020-4136-3

\section{Publisher's Note}

Springer Nature remains neutral with regard to jurisdictional claims in published maps and institutional affiliations.

\section{Ready to submit your research? Choose BMC and benefit from:}

- fast, convenient online submission

- thorough peer review by experienced researchers in your field

- rapid publication on acceptance

- support for research data, including large and complex data types

- gold Open Access which fosters wider collaboration and increased citations

- maximum visibility for your research: over $100 \mathrm{M}$ website views per year

At $\mathrm{BMC}$, research is always in progress.

Learn more biomedcentral.com/submissions 